\title{
First direct archosauromorph remains from the Early-Middle Triassic transition of the Iberian Peninsula
}

\author{
Martín D. Ezcurra, Josep Fortuny, Eudald Mujal, and Arnau Bolet
}

\begin{abstract}
This paper discusses the taxonomic affinities of three isolated teeth discovered in the Buntsandstein facies of the Catalan Coastal Ranges and central-eastern Pyrenean basins that crop out in Catalonia, north-eastern Spain. The tooth crowns are blade-like, labiolingually compressed, distally recurved, and proportionally apicobasally tall, in which the most complete of them is at least 2.4 times taller than its mesiodistal depth at base. The distal margins possess a densely serrated carina, and the mesial margins lack carina and serrations. The enamel of the crowns lacks ornamentation (e.g., wrinkles, ridges) or macroscopic wear-facets. The three teeth are referred to indeterminate crocopodan archosauromorphs based on the presence of labiolingually compressed and serrated crowns. The absence of mesial denticles resembles the condition in the non-archosauriform archosauromorph Teyujagua, proterosuchids, and some more crownward archosauriforms (e.g., some proterochampsids). We could not find evidence to determine if these teeth belong to a single or multiple closely related species. These remains represent the first direct archosauromorph remains from Lower-Middle Triassic beds of the Iberian Peninsula and add information about the geographic distribution of the group during the dawn of the evolutionary radiation of the group.
\end{abstract}

Martín D. Ezcurra. Sección Paleontología de Vertebrados, Museo Argentino de Ciencias Naturales, Av. Ángel Gallardo 470, C1405DJR, Buenos Aires, Argentina. School of Geography, Earth and Environmental Sciences, University of Birmingham, Birmingham, United Kingdom. martindezcurra@yahoo.com.ar Josep Fortuny. Institut Català de Paleontologia M. Crusafont. Z building, Universitat Autònoma de Barcelona, 08193 Cerdanyola del Vallès, Barcelona, Spain. Centre de Recherches en Paléobiodiversité et Paléoenvironnements, UMR 7207, Muséum National d'Histoire Naturelle, Bâtiment de Paléontologie, CP38, 8 rue Buffon, 75005 Paris, France. josep.fortuny@icp.cat Eudald Mujal. Departament de Geologia, Universitat Autònoma de Barcelona, 08193, Bellaterra, Barcelona, Spain. eudald.mujal@gmail.com Arnau Bolet. Institut Català de Paleontologia M. Crusafont. Z building, Universitat Autònoma de Barcelona, 08193 Cerdanyola del Vallès, Barcelona, Spain. arnau.bolet@icp.cat

Keywords: Diapsida; Archosauromorpha; Crocopoda; teeth; Early-Middle Triassic

Submission: 23 May 2016 Acceptance: 5 December 2017

\footnotetext{
Ezcurra, Martín D., Fortuny, Josep, Mujal, Eudald, and Bolet, Arnau. 2017. First direct archosauromorph remains from the EarlyMiddle Triassic transition of the Iberian Peninsula. Palaeontologia Electronica 20.3.62A: 1-10. https://doi.org/10.26879/686 palaeo-electronica.org/content/2017/1855-archosauromorphs-from-spain 


\section{INTRODUCTION}

The Permo-Triassic mass extinction (ca. 252 m.y.a.) allowed the flourishing of multiple vertebrate clades that were minor components of Palaeozoic assemblages or originated in the aftermath of this event. One of the clades that radiated during the Triassic was Archosauromorpha, which includes the diapsids, more closely related to crocodiles and dinosaurs (including birds) than to lepidosaurs (Gauthier et al., 1988). The oldest archosauromorphs are middle-late Permian in age (Ezcurra et al., 2014; Martinelli et al., 2016) and during the Triassic achieved disparate morphologies and ecological habits, including the specialized herbivorous rhynchosaurs, allokotosaurians, ornithischians, and sauropodomorphs, the bulky carnivorous erythrosuchids and "rauisuchians", the aquatic or semi-aquatic tanystropheids and at least some proterochampsids and poposauroids, and the flying pterosaurs (Nesbitt, 2011; Ezcurra, 2016). The clade suffered several biotic crises during its evolutionary history, such as those of the Triassic-Jurassic and Cretaceous-Palaeogene mass extinctions, but they are abundantly represented in extant ecosystems by more than 10,000 species, mostly corresponding to birds. The Early Triassic archosauromorph record is mainly restricted to species with a low morphological diversity (Ezcurra and Butler, 2015). Otherwise, during the Anisian (247-242 m.y.a.) several of the above-mentioned eco-morphotypes appear or become more abundant probably as a result of the stabilization of ecosystems recovered from the mass extinction event (Irmis and Whiteside, 2012; Lau et al., 2016). As a result, the Early-Middle Triassic transition is a key interval to understand the subsequent evolutionary success of archosauromorphs.

The European late Olenekian-Anisian archosauromorph record is relatively rich, but that of the Iberian Peninsula is restricted to ichnites from the Buntsandstein and Muschelkalk facies (Lapparent et al., 1965; Calafat et al., 1987; Fortuny et al., 2011a; Mujal et al., 2016, 2017). The only named Iberian Middle Triassic archosauromorph species is the tanystropheid Cosesaurus aviceps from the Ladinian of the Montral-Alcover Basin (Ellenberger and Villalta, 1974; Sanz and López-Martínez, 1984). Cosesaurus aviceps is based on a fairly complete skeleton preserved as natural moulds and is probably closely related to derived tanystropheids (e.g., Amotosaurus rotfeldensis, Tanystropheus longobardicus) based on the presence of an elongated, metatarsal-like pedal phalanx $\mathrm{V}-1$
(MGB-V1, see synapomorphies within Tanystropheidae in Ezcurra, 2016). Here we describe and discuss the taxonomic affinities of three isolated archosauromorph teeth discovered in the Buntsandstein facies of the Catalan Coastal Ranges and Catalan Pyrenees, north-eastern Iberian Peninsula (Spain) (Figure 1). These remains represent the first archosauromorph direct fossils from Early-Middle Triassic beds of the Iberian Peninsula.

\section{Geological and Palaeontological Setting}

The archosauromorph teeth were recovered in two outcrops from the north-eastern region of the Iberian Peninsula (Catalonia, Spain). In the Iberian Peninsula, the Triassic is composed of the classic German lithofacies: Buntsandstein, Muschelkalk, and Keuper. All the remains here reported come from the Buntsandstein facies.

The tooth IPS-90631 comes from the La Mora site of the Catalan Basin, the Triassic beds of the current Catalan Coastal Ranges, and was collected during fieldwork conducted in 2008. This site yielded hundreds of fossil bones assigned mainly to temnospondyl amphibians and to a lesser

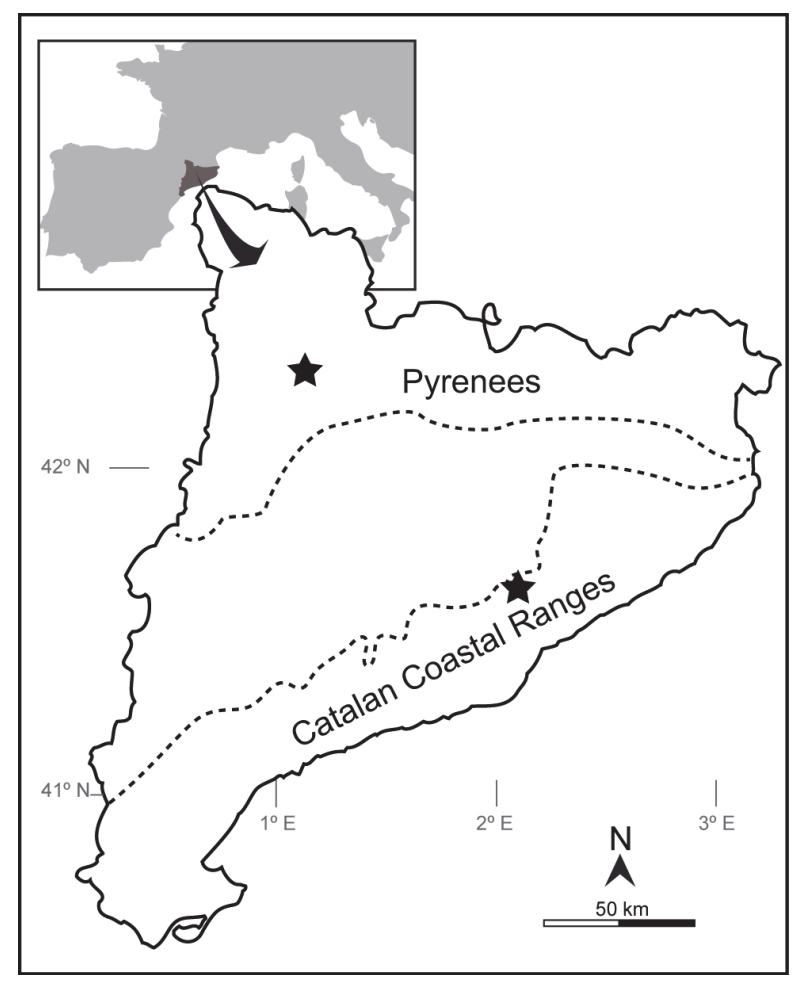

FIGURE 1. Map of Catalonia showing the geographic occurrence of the archosauromorph teeth described here. Dashed lines indicate the boundary of each mountain range. 
degree amniotes (Fortuny et al., 2011a, 2011b, 2014). La Mora site belongs to the Montseny-Llobregat domain of the Catalan Basin (Calvet and Marzo, 1994). The Buntsandstein facies in this area (lower part of the Areniscas $y$ Lutitas del Figaró unit) are formed by continental deposits, mainly composed of sandstones, mudstones, and red clays, being interpreted as fluvial deposits (Calvet and Marzo, 1994). The age of this unit is unclear, but based on palynological, palaeomagnetostratigraphic, and biostratigraphic evidence the lower part of this unit (including the La Mora site) is considered as early to middle Anisian (Middle Triassic) (see Dinarès-Turell et al., 2005; Fortuny et al., 2011b and references therein for further stratigraphical and sedimentological details).

The teeth IPS-73757 and IPS-90188 and a few bone fragments were recovered from the Triassic levels of the Pyrenean Basin that crop out in the Port del Cantó site in fieldworks corresponding to years 2012 (for IPS-73757) and 2014 (for IPS90188). In the earliest Triassic, the Pyrenees were composed of several continental sedimentary basins developed in the latest phases of the Variscan cycle, resulting from a strike-slip (transtentional) tectonic activity (Speksnijder, 1985; Saura, 2004; Saura and Teixell, 2006; Izquierdo-Llavall et al., 2014; Gretter et al., 2015). In this extensional regime, the Triassic sediments covered the Variscan basement and the Permo-Carboniferous vulcanosedimentary sequences, configuring an erosive angular unconformity. The region of Port del Cantó belongs to the central Nogueres structural zone (Saura, 2004). The reference studies by Mey et al. (1968) and Nagtegaal (1969) defined the "post-hercynian" units of the Catalan Pyrenees. Séguret (1972) and Zwart (1979) conducted the basic regional geology and mapping, and recent structural works are those of Saura (2004) and Saura and Teixell (2006). The basin architecture and evolution has been largely studied (Speksnijder, 1985; Saura and Teixell, 2006; Izquierdo-Llavall et al., 2014; Gretter et al., 2015). A revision of the Triassic vertebrate content has been addressed by Fortuny et al. (2011a), and more recently Mujal et al. $(2016,2017)$ revised and provided new data on the Permo-Triassic transition.

In Port del Cantó, the Buntsandstein facies reach a maximum thickness of $350 \mathrm{~m}$ (Mujal et al., 2017), and the sequence is divided in three main units (sensu of Calvet et al., 1993), from base to top: (1) conglomerate unit, composed of fluvial braided oligomictic conglomerates (mostly of quartz pebbles) and medium to very coarse chan- nel-fill sandstones; (2) shale and sandstones unit, composed of reddish and greenish to greyish medium-coarse sandstones, with some discontinuous conglomerate levels, of meandering fluvial settings, and reddish very fine to fine sandstones and shales of floodplain systems; and (3) shale unit, composed of reddish shales with occasional thin but continuous sandstone beds (as those of the shale and sandstones unit) corresponding to floodplain deposits and minor channels. The Buntsandstein facies represent the thickest Triassic sequences of the Catalan Pyrenean Basin, followed by the transitional to marine Muschelkalk and Keuper facies (Figure 2).

The reported teeth were recovered in the uppermost part of the Buntsandstein shale and sandstones unit, $42 \mathrm{~m}$ below the transition to the Muschelkalk facies. They were found in a fining upwards interval composed of fine- to mediumgrained cross laminated sandstones displayed in thin (ca. $5 \mathrm{~cm}$ ) layers of low lateral extension interbedded with reddish mudstones. Root traces, invertebrate burrows, and low-developed palaeosols (thin mudstone levels with carbonate nodules) are also present. This interval is interpreted as small crevasse splay deposits of floodplain systems (Mujal et al., 2017). The teeth and bone fragments were in close association (less than two square metres in horizontal axis, and a few centimetres in stratigraphic level).

The palynological analysis of Calvet et al. (1993) indicated an early Anisian (early Middle Triassic) age for the shale unit of the Buntsandstein facies (see also Diez et al., 2005, 2010). Mujal et al. (2016) described a palynological assemblage from the base of the shale and sandstones unit corresponding to the late Olenekian (late Early Triassic). Therefore, the age interval for the teeth IPS73757 and IPS-90188 is late Early-early Middle Triassic.

\section{Institutional Abbreviations}

BP, Evolutionary Studies Institute (formerly Bernard Price Institute for Palaeontological Research), University of the Witwatersrand, Johannesburg, South Africa; IPS, Institut Català de Paleontologia Miquel Crusafont, Sabadell, Spain; IVPP, Institute of Vertebrate Paleontology and Paleoanthropology, Beijing, China; MCZ, Museum of Comparative Zoology, Cambridge, USA; MGB, Nat-Museu de Ciències Naturals de Barcelona, Barcelona, Spain; RC, Rubidge Collection, Wellwood, Graaff-Reinet, South Africa; SAM-PK, Iziko South African Museum, Cape Town, South Africa; SMNS, Staatli- 


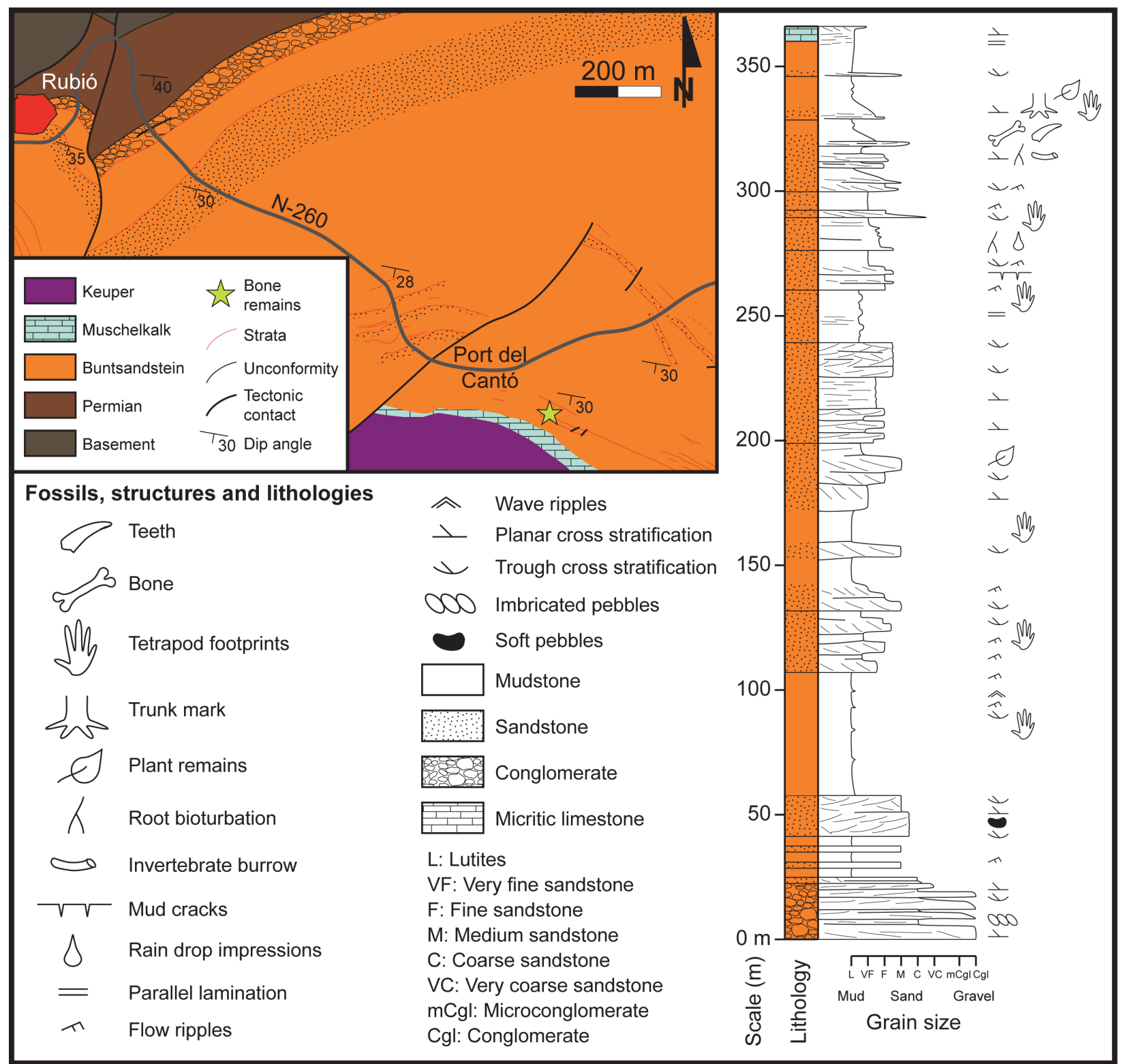

FIGURE 2. Geological map and stratigraphic profile of the Port del Cantó locality where IPS-73757 and IPS-90188 were collected.

ches Museum für Naturkunde Stuttgart, Stuttgart, Germany; UA, University of Antananarivo, Antananarivo, Madagascar.

\section{SYSTEMATIC PALAEONTOLOGY}

DIAPSIDA Osborn, 1903 sensu Laurin, 1991 SAURIA Gauthier, 1984 sensu Gauthier, Kluge and Rowe, 1988

ARCHOSAUROMORPHA Huene, 1946 sensu Dilkes, 1998

CROCOPODA Ezcurra, 2016

Family incertae sedis
Gen. et sp. indet.

Figure 3

Material. IPS-90631: isolated tooth crown missing its apex, probably from the anterior region of the mouth (Figure 3.1; Table 1).

Locality and horizon. La Mora site, Catalonia, Spain. Buntsandstein facies (lower part of the Areniscas y Lutitas del Figaró unit), Montseny-Llobregat domain of the Catalan Basin, dated as early to middle Anisian (Fortuny et al., 2011b).

Description. IPS-90631 is identified as a possible shed tooth, detached from the tooth series when 

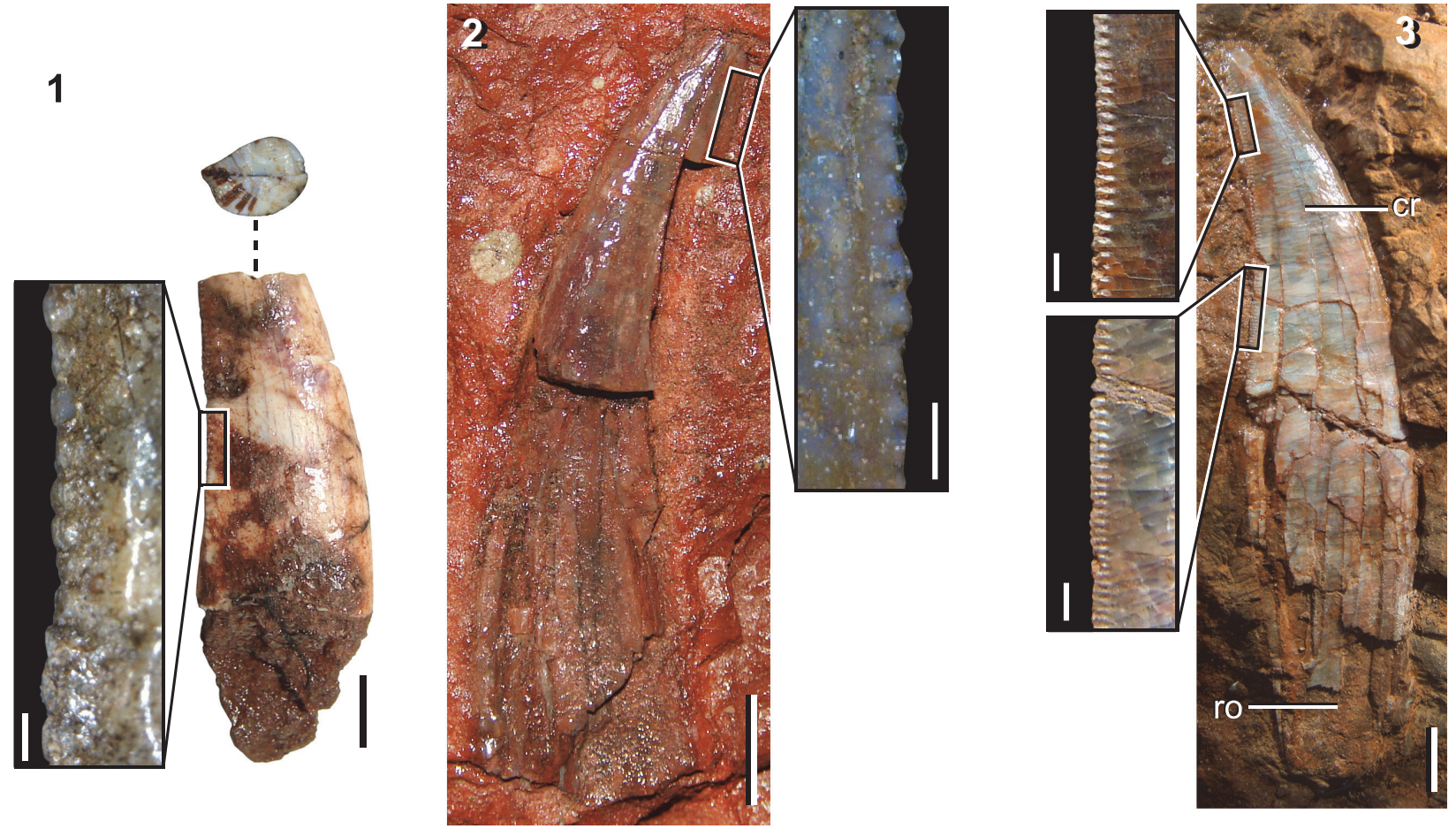

FIGURE 3. Isolated crocopodan archosauromorph teeth from the Early-Middle Triassic of Catalonia. 1, IPS-90631 in apical (top) and lingual (bottom) views and close up of distal denticles; 2, IPS-73757 in labial view and close up of distal denticles; 3, IPS-90188 in side view and close up of distal denticles. Abbreviations: cr, crown; ro, root. Scale bars equal $2 \mathrm{~mm}$ in (1), $5 \mathrm{~mm}$ in (2,3), $0.2 \mathrm{~mm}$ in close up of (1), $0.5 \mathrm{~mm}$ in close up of (2), and $1 \mathrm{~mm}$ in close ups of (3).

the animal was alive, because the crown is broken around its base and, as a result, the root is missing (Figure 3.1; Table 1). Nevertheless, no resorption pit is preserved to confirm unambiguously this interpretation. The apex of the crown is missing and the most apically preserved portion possesses a fresh broken surface, indicating that its apex was probably lost after exposure of the specimen. The crown is asymmetric in distal view, in which the inferred labial surface is more convex apicobasally than the lingual surface. The distal carina of the crown is slightly lingually displaced from the main mesiodistal axis of the tooth and, as a result, this dental element would have belonged to the anterior region of the mouth (where the alveolar margin of the snout arches medially). The preserved portion of the crown is blade-like, being slightly distally recurved in side view and distinctly labiolingually compressed. The crown possesses a serrated distal carina, in which the main axis of the denticles is perpendicular to that of the crown. The distal margin of the denticles is straight to slightly apicobasally convex. The interdenticular sulci are shallow and not extend onto the rest of the crown as blood grooves. The serrations extend along most of the distal margin of the crown, with a density of five denticles per millimetre, and they are absent at its base. The mesial margin of the crown lacks a carina and serrations, being continuously labiolingually convex. The enamel of the crown lacks ornamentation (e.g., wrinkles, ridges) or macroscopic wear-facets in its preserved portion.

Material. IPS-73757: isolated tooth crown from the middle or posterior region of the mouth, with its apical half - missing the tip and part of the distal margin - exposed in probable labial view and distal half preserved as the natural mould of its lingual surface (Figure 3.2; Table 1); IPS-90188: isolated complete tooth exposed in probable labial view (Figure 3.3; Table 1).

Locality and horizon. Port del Cantó site, Catalonia, Spain. Buntsandstein facies of the Pyrenean Basin dated as late Olenekian-early Anisian (Calvet et al., 1993; Fortuny et al., 2011a; Mujal et al., 2016, 2017).

Description. IPS-73757 is an isolated tooth probably exposed in labial view because it possesses a faint bowing towards the side that is covered with matrix in mesial or distal view (Figure 3.2). The apical half of the preserved portion of the tooth lacks its tip and part of the distal margin. The distal half is preserved as the natural mould of the probable lin- 
TABLE 1. Measurements of the crocopodan archosauromorph teeth here described in millimetres. Values between brackets indicate incomplete measurements. Maximum deviation of the digital calliper is $0.02 \mathrm{~mm}$ but measurements were rounded to the nearest 0.1 millimetre.

\begin{tabular}{lccc}
\hline \multicolumn{1}{c}{ Measurements } & $\begin{array}{c}\text { La Mora tooth } \\
\text { (IPS-90631) }\end{array}$ & $\begin{array}{c}\text { Port del Cantó tooth } \\
\text { (IPS-73757) }\end{array}$ & $\begin{array}{c}\text { Port del Cantó tooth } \\
\text { (IPS-90188) }\end{array}$ \\
\hline Apicobasal height of crown+root & $?$ & $?$ & $(58.7)$ \\
Apicobasal height of crown & $(10.0)$ & $(38.7)$ & $(29.8)$ \\
Mesiodistal depth of crown at base & 4.9 & ca. 13.0 & 12.9 \\
Labiolingual width of crown at base & 3.4 & $?$ & $?$ \\
\hline
\end{tabular}

gual surface. The preserved portion continuously expands mesiodistally towards its base and the boundary between the crown and root (if present) cannot be determined. IPS-90188 is a complete tooth, preserving crown and root, exposed probably in labial view because the crown bows towards the rock (Figure 3.3). In both specimens there is a series of longitudinal cracks (also present in the natural mould of IPS-73757), but otherwise they are well preserved. The two specimens from the Port del Cantó site possess a fairly congruent morphology between each other and they are described together as follows.

The crowns are distally recurved along their entire extension and, as a result, their apexes are placed distally to the distal margin of their bases. The crowns are labiolingually compressed, with a more acute distal margin than the mesial margin. The crowns are proportionally tall, being at least 2.4 times taller than its mesiodistal depth at base in IPS-90188 (Figure 3.3: cr). The distal margin possesses a sharp and serrated carina and, at least, in IPS-73757 there are no carina and serrations on the mesial margin of the preserved portion of the crown. The distal carina of IPS-73757 is aligned with the mesiodistal axis of the crown, indicating that it is not a tooth from the anterior region of the mouth. This feature cannot be determined confidently in IPS-90188. The denticles extend along the entire preserved portion of the distal margin of the crown in IPS-90188 and this condition cannot be determined in IPS-73757 because the actual distal half of the crown is missing. The morphology of the distal denticles of IPS-73757 closely resembles that of IPS-90631. The latter two specimens possess squared denticles, but in IPS-90188 they are proportionally mesiodistally longer, being subrectangular. The interdenticular sulci are shallow and not extend onto the rest of the crown as blood grooves. In both specimens, the most apical third of the crown possesses three denticles per millimetre, whereas around mid-height there are four denticles per millimetre. The enamel of the crown lacks ornamentation (e.g., wrinkles, ridges) or macroscopic wear-facets in its preserved portion. The root of IPS-90188 is probably complete, and there is no evidence of reabsorption at least in the exposed side (Figure 3.3: ro). The root expands gently mesiodistally along its most apical portion, as a continuation of the expansion towards the base present in the crown, and more basally it narrows gradually as a result of the convergence of the straight mesial and distal margins. The basal margin of the root is straight and, as a result, the root acquires an overall trapezoidal contour in side view.

\section{DISCUSSION}

The morphology of the three isolated teeth described here is rather consistent with each other, but they differ in the density and shape of the distal denticles. These features have not been used as characters in phylogenetic analyses focused on basal archosauromorphs (e.g., Dilkes, 1998; Nesbitt, 2011; Nesbitt et al., 2015; Pritchard et al., 2015; Ezcurra, 2016), and they seem to be taxonomically uninformative. In addition, the subtle differences observed in the morphology of the denticles may be attributable to variations within the dental series or intraspecific variability. Therefore, we could not find evidence to determine if the teeth described here belong to a single or multiple closely related species.

The three teeth share the presence of a labiolingually compressed and serrated crown, which are two character-states found in lesser inclusive clades of Archosauromorpha. Compressed crowns are present in several crocopodan archosauromorphs (sensu Ezcurra, 2016), namely azendohsaurids (e.g., Azendohsaurus madagaskarensis: UA 10603, 10604, 8-29-97-160), prolacertids (e.g., Prolacerta broomi: BP/1/2675), Teyujagua (Pinheiro et al., 2016), Tasmaniosaurus (Ezcurra, 2014) and archosauriforms (e.g., Proterosuchus fergusi: RC 846; Erythrosuchus afri- 
canus: BP/1/5207; Euparkeria capensis: SAM-PK5867). By contrast, the crowns are conical, with a circular cross-section, in non-crocopodan archosauromorphs and more basal diapsids, such as Youngina (BP/1/3859), tanystropheids (e.g., Tanystropheus: SMNS 54147), and Prolacertoides (IVPP V3233). The presence of small serrations is a more taxonomically restricted feature, being present in Teyujagua, Tasmaniosaurus, and archosauriforms among archosauromorphs (Ezcurra, 2016; Pinheiro et al., 2016). By contrast, other archosauromorphs lack finely serrated crowns (e.g., tanystropheids, prolacertids, trilophosaurids, rhynchosaurs; Benton and Clark, 1988; Juul, 1994; Dilkes, 1998; Nesbitt et al., 2015; Ezcurra, 2016; Pinheiro et al., 2016) and, although azendohsaurids possess denticles in the crown, they are considerably larger and coarser (with a lower density; Flynn et al., 2010; Nesbitt et al., 2015). As a result, recent quantitative phylogenetic analyses found compressed and finely serrated crowns as synapomorphies of lesser inclusive clades within Crocopoda (Ezcurra, 2016; Pinheiro et al., 2016) and support the assignment of the three teeth from the late Early to Middle Triassic of Catalonia to this clade.

The teeth described here also share the absence of mesial denticles in the crown. The occurrence of apically restricted, incipient, or absent mesial denticles has been scored for proterosuchids (e.g., Proterosuchus fergusi, "Chasmatosaurus" yuani) (Ezcurra, 2016) and more recently Teyujagua (Pinheiro et al., 2016) among basal archosauromorphs, whereas Kalisuchus rewanensis, Sarmatosuchus otschevi, erythrosuchids, and the vast majority of Triassic eucrocopodan archosauriforms possess densely serrated mesial carinae (Ezcurra, 2016). However, the presence of crowns with a serrated distal margin and lacking serrations in the mesial one convergently occur in disparate archosauriform groups, such as in some proterochampsids (e.g., Chanaresuchus bonapartei: MCZ 4686) and early dinosauriforms (MDE, personal observation). As a result, the absence of mesial denticles is not a character-state useful to unambiguously constrain the taxonomic assignment of blade-like, serrated archosauromorph teeth. Therefore, the three teeth described here for the late Early to Middle Triassic of Catalonia are assigned to indeterminate crocopodan archosauromorphs. The teeth described here indicate the presence of small-sized predatory archosauromorphs in the late Olenekian-early Anisian tetrapod assemblage of the Iberian Peninsula. The currently available sample is very low and restricted to morphologically similar crowns, but it is a first step towards a better knowledge of the late Early-early Middle Triassic archosauromorph diversity in this part of Europe. These remains represent the first archosauromorph direct fossils from beds of this age in the Iberian Peninsula and add information about the geographic distribution of the group during the dawn of the evolutionary radiation of the group.

\section{ACKNOWLEDGEMENTS}

Our special thanks to J.Á. López, M. Plà, A. Vidal, A. López, J. Palau, M. Garriga, M. Cortina, J.M. Marmi, A.G. Sellés, E. Solà, Geoterna, X. Ros, J. Palomar, and À. Blanco for fieldwork help. MDE thanks the following curators, researchers and collection managers that provided access to specimens under their care for the purpose of this research: B. Zipfel, B. Rubidge, J. Choiniere, and F. Abdala (BP); J. Liu and C. Sullivan (IVPP); J. Cundiff (MCZ); V. Vicedo (MGB); S. Kaal and R. Smith (SAM-PK); and R. Schoch (SMNS). Research of MDE was supported by a grant of the DFG Emmy Noether Programme (BU 2587/3-1 to Richard J. Butler) and a Marie Curie Career Integration Grant (PCIG14-GA-2013-630123 ARCHOSAUR RISE to Richard J. Butler). JF is financially supported by the postdoc grant "Beatriu de Pinos" 2014 - BP-A 00048 from Generalitat de Catalunya and EM by a PIF grant of the Geology Department (UAB). The project "La Terra abans dels dinosaures" (ref. 57 641992013 03) is acknowledged and was financed by the Parc Natural de l'Alt Pirineu (Catalonia, Spain). Fieldworks were performed under the projects "Vertebrats del Permià i el Triàsic de Catalunya i el seu context geològic" and "Evolució dels ecosistemes amb faunes de vertebrats del Permià i el Triàsic de Catalunya" (ref. 2014/100606) financially supported by the Departament de Cultura (Generalitat de Catalunya). We thank the comments of two anonymous reviewers. 


\section{REFERENCES}

Benton, M.J. and Clark, J.M. 1988. Archosaur phylogeny and the relationships of the Crocodylia, p. 295-338. In Benton, M.J. (ed.), The Phylogeny and Classification of the Tetrapods. Volume 1. Amphibians, Reptiles, and Birds. Clarendon Press, Oxford.

Calafat, F., Fornós, J.J., Marzo, M., Ramos-Guerrero, E., and Rodríguez-Perea, A. 1987. Icnología de vertebrados de la facies Buntsandstein de Mallorca. Acta Geológica Hispánica, 21-22:515-520.

Calvet, F. and Marzo, M. 1994. El Triásico de las Cordilleras Costero Catalanas. Estratigrafía, Sedimentología y Análisis Secuencial. Field Guide III Coloquio de Estratigrafía y Sedimentología del Triásico y Pérmico de España, Cuenca.

Calvet, F., Solé de Porta, N., and Salvany, J.M. 1993. Cronoestratigrafía (Palinología) del Triásico Sudpirenaico y del Pirineo Vasco-Cantábrico. Acta Geologica Hispanica, 28:33-48.

Diez, J.B., Broutin, J., and Ferrer J. 2005. Difficulties encountered in defining the PermianTriassic boundary in Buntsandstein facies of the western Peritethyan domain based on palynological data. Palaeogeography, Palaeoclimatology, Palaeoecology, 229:40-53. https:// doi.org/10.1016/j.palaeo.2005.06.029

Diez, J.B., Broutin, J., Grauvogel-Stamm, L., Bourquin, S., Bercovici, A., and Ferrer, J. 2010. Anisian floras from the NE Iberian Peninsula and Balearic Islands: A synthesis. Review of Palaeobotany and Palynology, 162:522-542. https://doi.org/10.1016/j.revpalbo.2010.09.003

Dilkes, D.W. 1998. The Early Triassic rhynchosaur Mesosuchus browni and the interrelationships of basal archosauromorph reptiles. Philosophical Transactions of the Royal Society of London B, 353:501-541. http://doi:10.1098/rstb.1998.0225

Dinarès-Turell, J., Diez, J.B., Rey, D., and Arnal, I. 2005. "Buntsandstein" magnetostratigraphy and biostratigraphic reappraisal from eastern Iberia: Early and Middle Triassic stage boundary definitions through correlation to Tethyan sections. Palaeogeography, Palaeoclimatology, Palaeoecology, 229:158-177. https://doi.org/10.1016/ j.palaeo.2005.06.036

Ellenberger, P. and Villalta, J.F. de. 1974. Sur la presence d'un ancêtre probable des oiseaux dans le Muschelkalk supérieure de Catalogne (Espagne). Note preliminaire. Acta Geologica Hispanica, 9:162-168.

Ezcurra, M.D. 2014. The osteology of the basal archosauromorph Tasmaniosaurus triassicus from the Lower Triassic of Tasmania, Australia. PLoS ONE, 9:e86864. https:// doi.org/10.1371/journal.pone.0086864

Ezcurra, M.D. 2016. The phylogenetic relationships of basal archosauromorphs, with an emphasis on the systematics of proterosuchian archosauriforms. PeerJ, 4:e1778. https:// doi.org/10.7717/peerj. 1778

Ezcurra, M.D. and Butler, R.J. 2015. Taxonomy of the proterosuchid archosauriforms (Diapsida: Archosauromorpha) from the earliest Triassic of South Africa, and implications for the early archosauriform radiation. Palaeontology, 58:141-170. https://doi.org.10.1111/pala.12130

Ezcurra, M.D., Scheyer, T.M., and Butler, R.J. 2014. The origin and early evolution of Sauria: reassessing the Permian saurian fossil record and the timing of the crocodile-lizard divergence. PLoS ONE, 9:e89165. https://doi.org/10.1371/journal.pone.0089165

Flynn, J.J., Nesbitt, S.J., Parrish, J.M., Ranivoharimanana, L., and Wyss, A.R. 2010. A new species of Azendohsaurus (Diapsida: Archosauromorpha) from the Triassic Isalo Group of southwestern Madagascar: cranium and mandible. Palaeontology, 53:669-688. https:// doi.org/10.1111/j.1475-4983.2010.00954.x

Fortuny, J., Bolet, A., Sellés, A.G., Cartanyà, J., and Galobart, À. 2011a. New insights on the Permian and Triassic vertebrates from the Iberian Peninsula with emphasis on the Pyrenean and Catalonian basins. Journal of Iberian Geology, 37:65-86. https://doi.org/10.5209/ rev_JIGE.2011.v37.n1.5

Fortuny, J., Bolet, A., Sellés, A.G., and Galobart, À. 2014. A potential record of a procolophonid parareptile from the Triassic of the Iberian Peninsula. Geologica Acta, 12:121-126.

Fortuny, J., Galobart, À., and De Santisteban, C. 2011b. A new capitosaur from the Middle Triassic of Spain and the relationships within the Capitosauria. Acta Palaeontologica Polonica, 56:553-566. http://dx.doi.org/10.4202/app.2010.0025

Gauthier, J.A. 1984. A Cladistic Analysis of the Higher Categories of the Diapsida. Unpublished Ph.D. Thesis, University of California, Berkeley, USA. 
Gauthier, J.A., Kluge, A.G., and Rowe, T. 1988. Amniote phylogeny and the importance of fossils. Cladistics, 4:105-209.

Gretter, N., Ronchi, A., López-Gómez, J., Arche, A., De la Horra, R., Barrenechea, J.F., Lago, M. 2015. The Late Palaeozoic-Early Mesozoic from the Catalan Pyrenees (Spain): 60 Myr of environmental evolution in the frame of the western peri-Tethyan palaeogeography. EarthScience Reviews, 150:679-708. https://doi.org/10.1016/j.earscirev.2015.09.001

Irmis, R.B. and Whiteside, J.H. 2012. Delayed recovery of non-marine tetrapods after the endPermian mass extinction tracks global carbon cycle. Proceedings of the Royal Society $B$, 279:1310-1318. https:doi.org/10.1098/rspb.2011.1895

Izquierdo-Llavall, E., Casas-Sainz, A., Oliva-Urcia, B., and Scholger, R. 2014. Palaeomagnetism and magnetic fabrics of the Late Palaeozoic volcanism in the Castejón-Laspaúles basin (Central Pyrenees). Implications for palaeoflow directions and basin configuration. Geological Magazine, 151:777-797. https://doi.org/10.1017/S0016756813000769

Juul, L. 1994. The phylogeny of basal archosaurs. Palaeontologia Africana, 31:1-38.

Lapparent, A.F.d., Le Joncour, M., Mathieu, A., and Plus, B. 1965. Découverte en Espagne d'empreintes de pas de Reptiles mésozoïques. Boletin de la Real Sociedad Española de Historia Natural, Sección Geológica, 63:225-230.

Lau, K.V., Maher, K., Altiner, D., Kelley, B.M., Kump, L.R., Lehrmannd, D.J., Silva-Tamayo, J.C., Weaver, K.L., Yu, M., and Payne, J.L. 2016. Marine anoxia and delayed Earth system recovery after the end-Permian extinction. Proceedings of the National Academy of Sciences, 113:2360-2365. https://doi.org/10.1073/pnas.1515080113

Laurin, M. 1991. The osteology of a Lower Permian eosuchian from Texas and a review of diapsid phylogeny. Zoological Journal of the Linnean Society, 101:59-95. https://doi.org/ 10.1111/j.1096-3642.1991.tb00886.x

Martinelli, A.G., Francischini, H., Dentzien-Dias, P.C., Soares, M.B., and Schultz, C.L. 2016. The oldest archosauromorph from South America: postcranial remains from the Guadalupian (mid-Permian) Rio do Rasto Formation (Paraná Basin), southern Brazil. Historical Biology, 29: 76-84. http://dx.doi.org/10.1080/08912963.2015.1125897

Mey, P.H.W., Nagtegaal, P.J.C., Roberti, K.J., and Hartevelt, J.J.A. 1968. Lithostratigraphic subdivision of post-Hercynian deposits in the south-central Pyrenees, Spain. Leidse Geologische Mededelingen, 44:221-228.

Mujal, E., Gretter, N., Ronchi, A., López-Gómez, J., Falconnet, J., Diez, J.B., de la Horra, R., Bolet, A., Oms, O., Arche, A., Barrenecha, J.F., Sébastien-Steyer, J., and Fortuny, J. 2016. Constraining the Permian/Triassic transition in continental environments: Stratigraphic and paleontological record from the Catalan Pyrenees (NE Iberian Peninsula). Palaeogeography, Palaeoclimatology, Palaeoecology, 445:18-37. https://doi.org/10.1016/j.palaeo.2015.12.008

Mujal, E., Fortuny, J., Bolet, A., Oms, O., and López, J.Á. 2017. An archosauromorph dominated ichnoassemblage in fluvial settings from the late Early Triassic of the Catalan Pyrenees (NE Iberian Peninsula). PLoS ONE 12(4): e0174693.

Nagtegaal, P.J.C. 1969. Sedimentology, paleoclimatology, and diagenesis of post- Hercynian continental deposits in the south-central Pyrenees, Spain. Leidse Geologische Mededelingen, 42:143-238.

Nesbitt, S.J. 2011. The early evolution of archosaurs: relationships and the origin of major clades. Bulletin of the American Museum of Natural History, 352:1-292.

Nesbitt, S.J., Flynn, J.J., Pritchard, A.C., Parrish, J.M., Ranivoharimanana, L., and Wyss, A.R. 2015. Postcranial osteology of Azendohsaurus madagaskarensis (?Middle to Upper Triassic, Isalo Group, Madagascar) and its systematic position among stem archosaur reptiles. Bulletin of the American Museum of Natural History, 398:1-126. https://doi.org/10.1206/ amnb-899-00-1-126.1

Osborn, H.F. 1903. The reptilian subclasses Diapsida and Synapsida and the early history of the Diaptosauria. Memoirs of the American Museum of Natural History, 1:449-519.

Pinheiro, F.L., França, M.A.G., Lacerda, M.B., Butler, R.J., and Schultz, C.L. 2016. An exceptional fossil skull from South America and the origins of the archosauriform radiation. Scientific Reports, 6:22817. https://doi.org/10.1038/srep22817

Pritchard, A.C., Turner, A.H., Nesbitt, S.J., Irmis, R.B., and Smith, N.D. 2015. Late Triassic tanystropheids (Reptilia, Archosauromorpha) from northern New Mexico (Petrified Forest Member, Chinle Formation) and the biogeography, functional morphology, and evolution of Tanystropheidae. Journal of Vertebrate Paleontology, 35:e911186. http://dx.doi.org/10.1080/ 02724634.2014 .911186 
Sanz, J.L. and López-Martínez, N. 1984. The prolacertid lepidosaurian Cosesaurus aviceps Ellenberger and Villalta, a claimed «Protoavian» from the Middle Triassic of Spain. Geobios, 17:747-755.

Saura, E. 2004. Anàlisi Estructural de la Zona de les Nogueres Pirineus Centrals. Unpublished Ph.D. thesis, Universitat Autònoma de Barcelona, Spain.

Saura, E. and Teixell, A. 2006. Inversion of small basins: effects on structural variations at the leading edge of the Axial Zone antiformal stack (Southern Pyrenees, Spain). Journal of Structural Geology, 28:1909-1920. https://doi.org/10.1016/j.jsg.2006.06.005

Séguret, M. 1972. Etude Tectonique des Nappes et Séries Décollés de la Partie Centrale du Versant sud des Pyrenées. Caractère synsédimentaire, rôle de la compression et de la gravité. Unpublished Ph.D. Thesis, Université de Montpellier, France.

Speksnijder, A. 1985. Anatomy of a strike-slip fault controlled sedimentary basin, Permian of the southern Pyrenees, Spain. Sedimentary Geology, 44:179-223.

Von Huene, F. 1946. Die grossen Stämme der Tetrapoden in den geologischen Zeiten. Biologisches Zentralblatt, 65:268-275.

Zwart, H.J. 1979. The Geology of Central Pyrenees. Leidse Geologische Mededelingen, 50:174. 